DOI: $\underline{\text { https://doi.org/10.31933/dijdbm.v2i5 }}$ Received: 15 August 2021, Revised: 10 September 2021, Publish: 28 September 2021

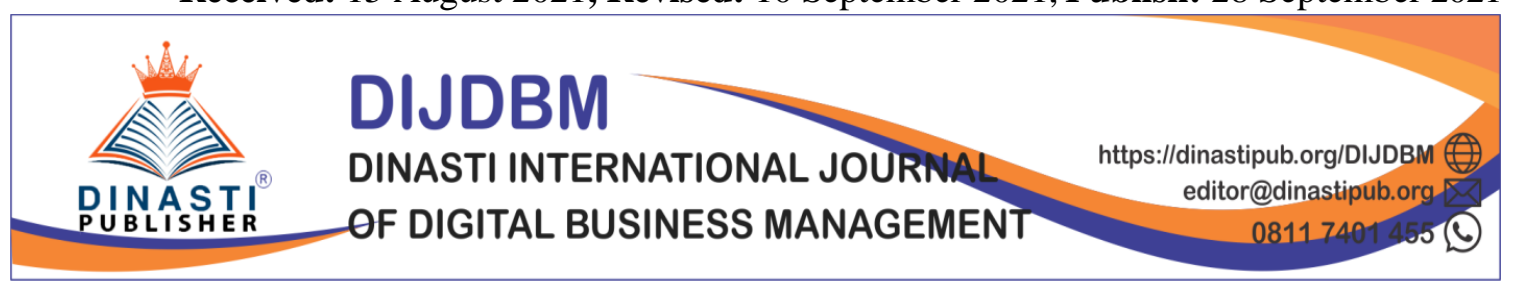

\title{
THE EFFECT OF COMPENSATION AND PERFORMANCE ASSESSMENT ON EMPLOYEE SATISFACTION THROUGH COMPETENCY AS A MEDIATION VARIABLE (CASE STUDY AT PT. VINDO INTERNATIONAL)
}

\author{
Setiyo Purwanto ${ }^{1}$, Didin Hikmah Perkasa ${ }^{2}$ \\ ${ }^{1)}$ Universitas Dian Nusantara, Indonesia, setiyo.purwanto@undira.ac.id \\ ${ }^{2)}$ Universitas Dian Nusantara, Indonesia, didin.hikmah.perkasa@undira.ac.id
}

\section{Corresponding Author: First Author}

\begin{abstract}
This research was conducted on the plastic manufacturing industry during the covid-19 pandemic. The purpose of this study was to examine the effect of compensation and performance appraisal on employee job satisfaction through competence as a mediating variable. The data in the study consisted of 150 populations and 109 samples in the study were employees of PT. Vindo International. Data analysis in this study used quantitative methods with the SmartPLS 3.0 test tool. Financial and non-financial compensation is part of the company's motivation to reward performance achievements. Providing appropriate compensation can provide employee job satisfaction and can trigger better performance. So that in the construction of this research a synergistic relationship is built in the provision of compensation accompanied by performance appraisals based on employee competencies, this will provide employee job satisfaction. Employee job satisfaction has an impact on performance, loyalty and awareness. All of this will shape the organizational culture to achieve company goals. The findings in this study are performance appraisals that are not based on employee competence can lead to individual subjectivity, this does not provide job satisfaction.
\end{abstract}

Keywords: Compensation, Performance Appraisal, Job Satisfaction, Competence.

\section{INTRODUCTION}

During the COVID-19 pandemic since March 2020, it is a difficult time for most industries to survive. Companies must rationalize costs by cutting various expenses (production bonuses, attendance incentives and achievement bonuses) as well as reducing employees significantly due to the effect of PSBB (Large-Scale Social Restrictions). This really paralyzes the business sector from small, medium to large scale. However, in any bad condition, the company must keep trying to survive by mobilizing various resources as well as doing a shifting strategy to rearrange organizational resources. Based on the study of human resource management literature according to D. Kenelak et.al (2016), explaining that, compensation given to employees can encourage work morale, there is a perceived satisfaction so that the performance output increases. However, the provision of compensation can not only motivate or provide employee job satisfaction. The provision of compensation that does not meet the principle of justice will be able to reduce motivation and job satisfaction, Aamir, Alemzeb (2012). Maheswari's research (2017) concludes that financial compensation has an effect on 
performance, but non-financial compensation has no effect on performance. In contrast to the results of Firmandari (2014) research which states that compensation in the form of bonuses does not have a significant effect on performance. Based on this research, it is important to give compensation to employees to revive morale, but there is a research gap where there must be an appropriate way of giving compensation.

Performance appraisal is also one of the performance measurement tools to place individual achievements at a certain grade/level as a form of corporate appreciation. This assessment is based on established regulations, by comparing the targets (work results) with the job description requirements, namely the work standards that have been set for a certain period, Widodo and Sami'an (2012:1). According to Rizal et al. (2013), the results of the performance appraisal will be a separate note in providing an assessment of each employee on the results (output) in terms of quality and quantity achieved. Assessment of employee performance in carrying out their duties does not always lead to job satisfaction for employees, there needs to be an alignment of tasks and employee abilities to achieve organizational goals, Mangkunegara (2015). Employee job satisfaction is a phenomenon that needs to be observed by organizational leaders. Someone who is satisfied will have high motivation, commitment to the organization and work participation, which in turn will improve his performance, Sinambela (2012).

Observing the existence of several inconsistencies in the findings of the research above, it encourages researchers to fill the research gap with competency variables as a mediating variable for compensation and performance appraisal on employee job satisfaction. According to Wibowo (2012: 323) explains that the competence of human resources will improve company performance and create organizational culture. Fiqri Surikha (2016) asserts that a person's competence is a reflection of employee professionalism as evidenced by the achievement of organizational performance. So that employee competencies can be used as standardization of employee performance appraisals in an effort to get compensation that must be given by the company.

\section{Problem Formulation}

Problems related to employee job satisfaction can be described as follows:

1. Whether compensation affect employee job satisfaction?

2. Whether Compensation affect Competence?

3. Whether Performance Appraisal affect Employee Job Satisfaction?

4. Whether Performance Assessment affect Competence?

5. Whether competency mediation affect employee job satisfaction?

6. Whether Compensation as measured through Competence affect Employee Job Satisfaction?

7. Whether Performance Assessment as measured by Competence affect Employee Job Satisfaction?

\section{Research Benefits}

Practical Benefits, making a positive contribution to the industry related to the effect of compensation and performance appraisal based on competence on employee job satisfaction so that they can further improve their performance in the future.

Theoretical benefits, add insight for academics related to Human Resource Management and provide references for academics who will conduct similar research or as a basis for developing research.

\section{LITERATURE REVIEW \\ Compensation}

Panggabean (2010) suggests that compensation is any form of award given to employees as a reward for the contributions they make to the organization. According to Rivai (2012), compensation is something that employees receive as a substitute for their service contribution to the company. Furthermore, the researcher Sikula (in Mangkunegara, 
2012) explains that compensation is a gift or gift as a comparable award. Sihotang (2012), added that compensation is an arrangement for providing remuneration, both financial and non-financial to each entitled employee.

The dimensions of compensation according to Hasibuan (2012) are explained, among others; Wages are usually related to the hourly rate of pay (more over time will be piad more). While the salary generally applies to weekly, monthly or yearly rates. Incentives are additional salaries beyond the normative salary provided by the organization. Incentive programs are tailored to productivity, sales, benefits or cost-cutting efforts. Benefits, such as health insurance, life insurance, company-borne holidays, pension plans and other benefits related to employment. Facilities is a pleasure as company car, club membership, dedicated parking.

\section{Performance Assessment}

Moeheriono (2012: 69) explains that, performance appraisal is a measure of work performance that has been achieved by an employee. According to Widodo in Sami'an (2012:1) it is emphasized that, performance appraisal aims to measure employee performance based on regulations that have been set by the company. Mondy and Noe in Sami'an (2012:2) add that a formal system is regularly used to evaluate individual performance in carrying out their duties. Junuari (2015) revealed that performance appraisal has a big influence on employee job satisfaction.

\section{Competence}

Competence of employees is needed in doing certain jobs. Employees who lack the ability or have low competence will find it difficult to do a job, lowering the quality and even hindering the completion of the work. Klarner, et al., 2013 have revealed that, it is very necessary for human resources who have adequate competence because competence is a key factor in improving employee performance. Yunus, 2012 and Rudlia, 2016 revealed that employee performance is strongly influenced by competence. Competence is something that is measurable, can be observed, predicted, and evaluated which is reflected in one's work behavior. Competence consists of a combination of knowledge (knowledge), skills, and attitudes. There are 5 dimensions of individual competence according to Moeheriono (2009), including; Task-skills; Task management skills; Contingency management skills; Job role environment skills; Transfer skills.

\section{Job Satisfaction}

Job satisfaction according to Mangkunegara (2013: 117) is a feeling that supports individual employees related to work. In addition, Mila Badriyah (2015) argues that job satisfaction is an employee's attitude or feeling towards pleasant or otherwise aspects of work.

\section{Relationship of Compensation to Job Satisfaction}

In a study conducted by Tett and Meyer in Sutanto and Gunawan (2013) stated that the desire to leave employees is based on an awareness of dissatisfaction with the compensation provided, so there is a desire to find alternative jobs in other organizations. This result is in line with previous findings by Yucel, (2012) which states that in his research, there is a negative effect of job satisfaction on the desire to leave. This means that if employees are satisfied with the compensation received, they are less likely to leave work. So that compensation can be used as a way to build employee job satisfaction. This research is reinforced by Sofyandi's theory (2013:162) that the purpose of compensation is to provide satisfaction to employees. In addition, T. Retnoningsih, B.S Sunuharjo, I. Ruhana, (2016) proved that non-financial compensation has a significant effect on employee job satisfaction. Based on the construct of the relationship, the researcher formulated hypothesis 1 as follows:

\section{H1: Compensation Affects Job Satisfaction}




\section{Relationship of Compensation to Competence}

According to Septerina and Rusda Irawati (2018), financial and non-financial compensation will improve employee work performance. Another opinion also states that the importance of employee competence as a standardization of individual abilities in providing appropriate compensation, Yunus (2012); Klarner, et al., (2013); Rudlia (2016). So that researchers arrange $\mathrm{H} 2$ as follows:

H2: Compensation Affects Competence

\section{The Relationship between Performance Assessment and Job Satisfaction}

Hasibuan, (2005:88) argues that, performance appraisal is an effort used by companies to assess employees carrying out their job duties. The results of this study strengthen the research of January, Utami, Ruhana (2015) which argues that performance appraisal has an effect on job satisfaction, even further explained that the better the implementation of performance appraisal, the higher job satisfaction. Andari, Nafiudin (2019) explained that performance appraisal has a positive effect on employee job satisfaction. Based on the construct of the relationship, the researcher formulated hypothesis 3 as follows:

H3: Performance Assessment Affects Job Satisfaction

\section{Relationship between Performance Assessment and Competence}

According to Hasibuan (2011) in his research explains that, performance appraisal based on individual competence is a measure for companies to select employees based on the required competencies. This research supports Wibowo (2014), which suggests the role of competence in the basis of performance appraisal because individual competence is the ability to carry out a job that is based on skills and knowledge and is supported by a good work attitude. Competence also describes skills and professionalism in a particular field as an advantage in their field. These results are in line with previous research conducted by Supatmi, Nimran, \& Utami, (2013), where it has been explained that job measurement is carried out as an effort to determine the level of employee performance in accordance with individual competencies. Based on the construct of the relationship, the researcher formulated hypothesis 4 as follows:

\section{H4: Performance Assessment Affects Competence}

\section{The Relationship of Competence to Job Satisfaction}

Measurement of individual competence value as the basis for initial compensation to be given by the company to provide satisfaction, Mathis and Jackson (2002:81). Dessler, (2004:70) also adds that the measurement of competence is equivalent to a person's knowledge, expertise, skills, and ability to do work. Based on the construct of the relationship, the researcher formulated hypothesis 5 as follows:

H5: Competence Affects Job Satisfaction.

\section{Relationship of Compensation to Job Satisfaction through Competence}

Dessler (2004:65) says that employee compensation is "Any form of payment or reward given to employees for their work". Giving awards must be adjusted to their competence to be able to motivate themselves to improve company performance, Rizwan (2014). Previous research conducted by Rahayu and Riana (2017) also argues that compensation given in accordance with their respective competencies has a positive and significant effect on job satisfaction, thereby reducing the desire to leave work. In another study also mentioned, the key to the success of a business organization is to increase the job satisfaction of its employees. Based on the results of research by Septerina and Rusda Irawati (2018), financial and non-financial compensation in accordance with individual competencies will provide employee job satisfaction. The results of this study are in accordance with research that has been carried out by several previous studies, namely: Nazir et al. (2013); Adeoye and Fields (2014); Rood and Holdnak (2013); Salisu et al. (2015); and Muguongo et al. (2015), who concluded that compensation in accordance with their competence has a positive and significant effect on job satisfaction. Another opinion is also in accordance with this study which states that the importance of employee competence as a standardization of individual abilities in providing 
appropriate compensation, so that job satisfaction can be fulfilled, Yunus (2012); Klarner, et al., (2013); Rudlia (2016). Based on this research, the researcher formulated hypothesis 6 as follows:

H6: Compensation Measured Through Competence Affects Job Satisfaction 7. The Relationship between Performance Assessment and Job Satisfaction through

\section{Competence}

According to Wibowo (2014) argues that, the role of competence in underpinning performance appraisal because individual competence is the ability to carry out a job based on skills and knowledge and supported by a good work attitude. These results are in line with the research of Supatmi, Nimran, \& Utami, (2013) which explains that, job measurement is carried out as an effort to determine the level of employee performance in accordance with individual competencies as the basis for providing compensation to meet employee job satisfaction. Based on the construct of the relationship, the researcher formulated hypothesis 7 as follows:

H7: Performance Assessment Measured Through Competence Affects Job Satisfaction

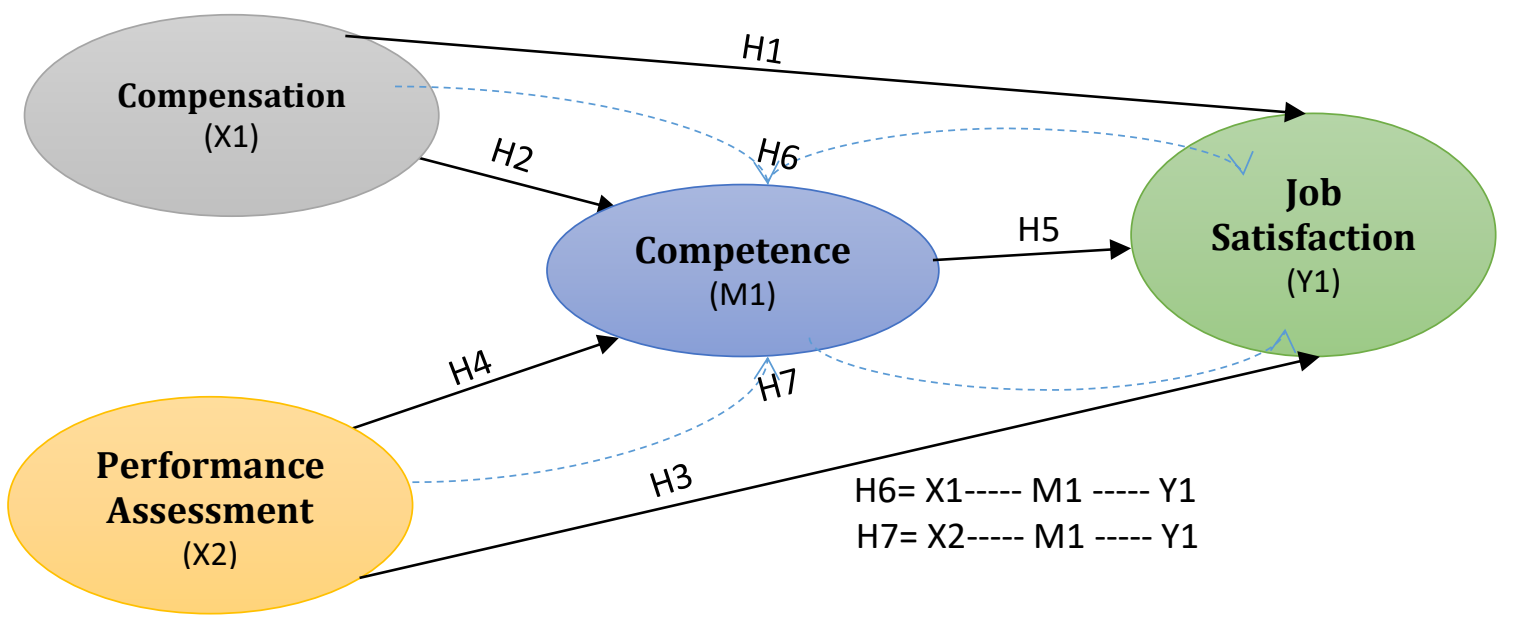

Figure 2.1 Research Model Construct

\section{RESEARCH METHOD}

The time of the research will be carried out in October to December 2020, as for the location of the object of research, namely: PT. Vindo International, Jl. Greater Industry III Block AD no. 18 Bunder Village, Cikupa District, Tangerang Regency 15710 Banten-Indonesia. This study is a descriptive study, which explains the relationship of compensation, performance appraisal and competence to employee job satisfaction with a total population of 150 employees.

\section{Sample}

The sample is part of the population that is used as the actual data source. In other words, the sample is part of the population. The sample is part of the number and characteristics possessed by the population, Sugiyono (2009: 116). Determination of the sample size to be taken in this study using the Slovin formula, Sanusi (2011:101). The Slovin formula for determining the sample is as follows:

$$
\mathrm{n}=\frac{\mathrm{N}}{1+\mathrm{N}(\mathrm{e})^{2}}
$$




\section{Information:}

$\mathrm{n}=$ Sample size/number of respondents

$\mathrm{N}=$ Population size

$\mathrm{e}=$ Percentage of allowance for accuracy of sampling error that can still be tolerated;

0.05. So the calculation of the research sample can be calculated as follows:

$$
\begin{aligned}
& \mathrm{n}=\frac{150}{1+\left(150(0,05)^{2}\right)} \\
& \mathrm{n}=\frac{150}{1,375} \\
& \mathrm{n}=109
\end{aligned}
$$

\section{Data Collection Techniques}

Data collection techniques carried out by researchers by distributing questionnaires to all employees to determine the effect of compensation and performance appraisal on employee job satisfaction mediated by competence.

\section{Data Analysis Method}

\section{Descriptive analysis.}

Descriptive analysis is used to describe and describe the variables used in this study (Sugiyono, 2017). Descriptive analysis was carried out using descriptive statistics that produced the average, maximum, minimum and standard deviation values to describe the research variables so that they were contextually easy to understand.

\section{Partial Least Square Analysis}

This model is used to determine the validity and reliability of linking indicators with latent variables. The indicators in this study are reflective because the indicators of latent variables affect the indicators, for this reason, 3 methods of measurement are used, Sofyan Yamin (2009), namely:

\section{Convergent Validity}

Convergent Validity measures the magnitude of the correlation between the construct and the latent variable. In evaluating convergent validity from checking individual item reliability, it can be seen from the standardized loading factor. The standardize loading factor describes the magnitude of the correlation between each measurement item (indicator) and its construct. The correlation can be said to be valid if it has a value $>0.5$.

\section{Discriminant Validity}

The next evaluation is to see and compare between discriminant validity and square root of average variance extracted (AVE). The measurement model was assessed based on the measurement of cross loading with the construct. If the correlation of the construct with each indicator is greater than the size of the other constructs, then the latent construct predicts the indicator better than the other constructs. If the AVE value is higher than the correlation value between the constructs, then good discriminant validity is achieved. According to Tasha Hoover (2005) in Sofyan Yamin (2011), it is highly recommended if the AVE is greater than 0.5. Here's the formula for calculating AVE:

$$
\mathrm{AVE}=\frac{\Sigma \lambda_{\mathrm{i} 2}}{\Sigma \lambda_{\mathrm{i}}{ }^{2}+\Sigma_{1 \operatorname{var}\left(\varepsilon_{\mathrm{i}}\right)}}
$$

Where $\lambda_{\mathrm{i}}$ is the loading factor (convergent validity), and $i=1-i 2$. Stating that this measurement can be used to measure reliability and the results are more conservative than the composite reliability value (pc) Fornnel and Larcker in Ghozali (2014).

\section{Composite Reliability}


To determine composite reliability, if the composite reliability value $>0.7$ it can be said that the construct has high reliability or reliable and $>0.6$ is said to be quite reliable Chin in Sofyan Yamin (2011). The following is the formula for calculating composite reliability:

$$
\left(\Sigma \lambda_{i}\right)^{2}
$$

$$
\rho c=\frac{\left(\Sigma \lambda_{\mathrm{i}}\right)^{2}+\Sigma_{1 \operatorname{var}\left(\varepsilon_{\mathrm{i}}\right)}}{\left(2 \lambda_{\mathrm{i}}{ }^{2}\right.}
$$

In PLS, the reliability test is strengthened by the presence of Cronbach alpha where the consistency of each answer is tested. Cronbach alpha is said to be good if 0.7 .

\subsection{Hypothesis Testing}

Based on the research objectives, the hypothesis test design that can be made is a hypothesis test design in this study which is presented based on the research objectives. The level of confidence used is $95 \%$, so the level of precision or the limit of inaccuracy is $(\alpha)=5 \%=$ 0.05 . And produce a t-table value of 1.96 . So, if the value of t-statistics is smaller than the value of t-table [t-statistics < 1.96], then Ho 0.5 is accepted and $\mathrm{Ha}$ is rejected. If the value of t-statistics is greater than or equal to t-table [t-statistics $>1.96$ ], then Ho is rejected and Ha is accepted.

\section{RESULTS AND DISCUSSION}

\section{Description of Research Object}

PT. Vindo International which has been established since 2007, is a plastic manufacturing company that has main business houseware equipment, oriented to the export and the domestic market. As an export-oriented company and has become a member of the Europe Sedex standardization where this standard is very concerned with employee welfare, the company is very concerned about the rights of employees as regulated in the Labor Law to ensure employee job satisfaction. Employees for the company are seen as very valuable assets, because no matter how great a management system and technology that is built/applied by the company, it will not achieve optimal performance without the important role of reliable human resources, Wibowo (2012:323); Suharti, 2012:39). Of the total number of questionnaires distributed and sent, namely 150 questionnaires, the total number of questionnaires filled out and returned was 148 questionnaires.

Table 4.1 List of questionnaires

\begin{tabular}{|l|c|}
\hline \multicolumn{1}{|c|}{ Questionnaire } & Quantity \\
\hline Questionnaire distributed & 150 \\
\hline Questionnaire wasn't returned & 2 \\
\hline Incomplete Questionnaire & 39 \\
\hline Appropriate questionnaire used for input purposes & 109 \\
\hline
\end{tabular}

\begin{tabular}{|c|c|c|}
\hline Information & Total & Percentage \\
\hline Total sample & 109 & $100 \%$ \\
\hline Gender: & & \\
\hline Male & 24 & $22 \%$ \\
\hline Female & 85 & $78 \%$ \\
\hline
\end{tabular}

Source: primary data processed 2020

Table 4.2 Respondent Profile 


\begin{tabular}{|l|l|l|}
$21-25$ years old & 29 & $26,6 \%$ \\
$26-30$ years old & 58 & $53,2 \%$ \\
$31-50$ years old & 22 & $20,2 \%$ \\
\hline
\end{tabular}

Source: primary data processed, 2021

Based on table 4.2, it is known that the number of female respondents is more than male respondents. This is due to the type of work in the finishing process and product packing that requires accuracy and patience, this type of skill is mostly owned by women up to 85 people (78\%) and men as many as 22 people (22\%). Most of the respondents were 26-30 years old, namely 58 people $(53.2 \%)$, respondents between $21-25$ years old were 29 people $(26.6 \%)$, and 22 people $30-40$ years old $(20,2 \%)$.

\subsection{Data Analysis}

The data processing technique using the Partial Least Square (PLS)-based SEM method requires 2 stages to assess the Fit Model of a research model (Ghozali, 2006). These stages are described as follows:

\subsubsection{Descriptive statistics}

Descriptive statistics is a method of collecting and presenting data so as to provide useful information, presenting both numerically and visualizing and classifying data using tables, in accordance with technological advances, (Ronald E. Walpole, 1993). Some indicators of research variables are not used in hypothesis testing, so that the presentation of descriptive statistical analysis will also not be included. Descriptive statistics are intended to analyze data based on the results obtained from respondents' answers to each variable measuring indicator. Descriptive statistical analysis can be seen in table 4.3.

Table 4. 3 Statistic Description

\begin{tabular}{|l|c|c|c|c|c|c|}
\hline \multicolumn{1}{|c|}{ Variable } & $\mathbf{N}$ & Minimum & Maximum & Median & Mean & $\begin{array}{c}\text { Standar } \\
\text { Deviasi }\end{array}$ \\
\hline Compensation & 109 & 22 & 35 & 30 & 31,055 & 3,885 \\
\hline $\begin{array}{l}\text { Performance } \\
\text { Assessment }\end{array}$ & 109 & 18 & 30 & 27 & 26,495 & 3,698 \\
\hline $\begin{array}{l}\text { Competence } \\
\text { Job } \\
\text { Satisfaction }\end{array}$ & 109 & 13 & 20 & 19 & 18,046 & 2,152 \\
\hline
\end{tabular}

Source: Processed primary data, 2021

Based on table 4.3 , it is shown that the compensation variable has a theoretical range between 22 and 35 with an average value of 31.055 and a standard deviation of 3.885 . With an average value of 31.055 which is higher than the median value of 30 , this indicates that the Compensation variable in general has a better perception. The Performance Appraisal variable has a theoretical range between 18 and 30 with an average value of 26,495 and a median of 27 and a standard deviation of 3,698. It can be seen that the average value is lower than the median, this indicates that the performance appraisal according to the respondent's perception is less trusted to fulfill a sense of justice (fearness) with an error rate of 3,698. The competence variable has a theoretical range of 13 to 20 with an average value of 18.046 and a standard deviation of 2.152. With an average value of 18.046 which is lower than the median of 19 , this indicates that according to the respondent's perception the Competence variable is less able to mediate in fulfilling Job Satisfaction with an error rate of 2.152. Job Satisfaction variable has a 
range between 23 to 30 with an average value of 28.027 and a standard deviation of 2.85 . With an average value of 28.027 and a median value of 28 , it can be said that job satisfaction is generally quite high. The standard deviation value indicates a deviation of 2.85 from the average value of respondents' answers to statements about 28.027.

\subsubsection{Model Construct}

Individual reflexive measures are said to be high if they correlate more than 0.70 with the construct being measured. However, according Chin, 1998 (in Ghozali, 2006) for research in the early stages of developing a scale for measuring factor loading values of 0.5 to 0.6 , it is considered sufficient. In this study, a loading factor limit of 0.60 will be used.

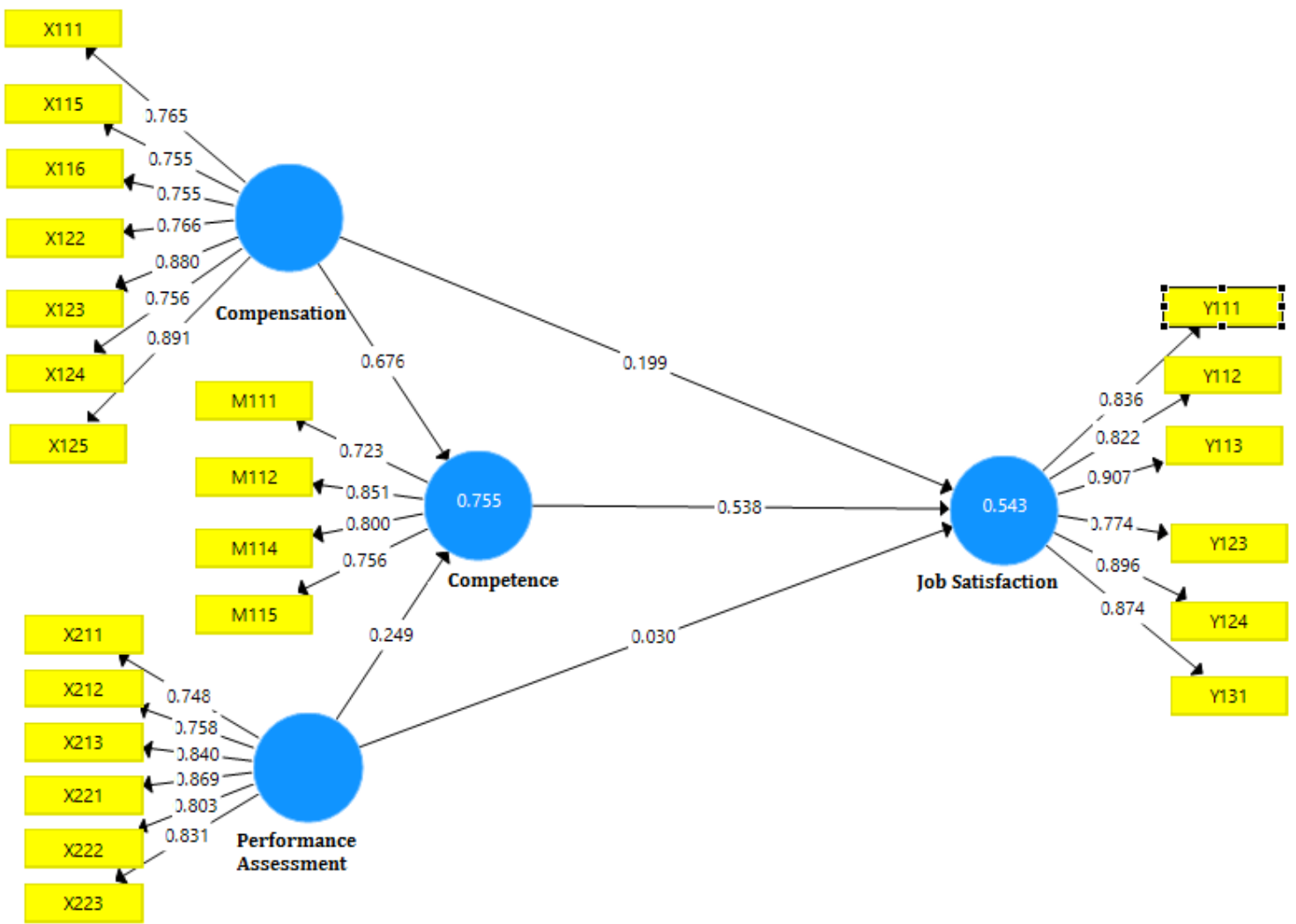

Figure 4.1. Research Model Fit

Source: Data processing with smartPLS, 2021

\subsubsection{Evaluating Reliability and Average Variance Extracted (AVE)}

Evaluation of the validity and reliability test is a statement test in the research construct to see whether the statements compiled by the researcher are valid and have consistency to meet the research objectives. The criteria for validity of the Average Variance Extracted (AVE) value and reliability can be seen from the Cronbach's Alpha value in each of the model constructs. A construct is said to have high reliability if its value is above 0.70 and AVE is above 0.50 . In table 4.5 the Composite Reliability and AVE values are presented for all variables.

Table 4. 5 Composite Reliability and Average Variance Extracted

\begin{tabular}{|c|c|c|c|c|}
\hline & $\begin{array}{c}\text { Cronbach's } \\
\text { Alpha }\end{array}$ & Rho_A & $\begin{array}{c}\text { Composite } \\
\text { Reliability }\end{array}$ & $\begin{array}{c}\text { Average Variance } \\
\text { Extracted (AVE) }\end{array}$ \\
\hline
\end{tabular}




\begin{tabular}{|l|c|c|c|c|}
\hline Job Satisfaction & 0,924 & 0,928 & 0,941 & 0,728 \\
\hline Compensation & 0,904 & 0,920 & 0,924 & 0,636 \\
\hline Competence & 0,790 & 0,793 & 0,864 & 0,615 \\
\hline $\begin{array}{l}\text { Performance } \\
\text { Assessment }\end{array}$ & 0,894 & 0,895 & 0,919 & 0,655 \\
\hline
\end{tabular}

Source: Data processing with smartPLS, 2021

Based on table 4.5 it can be concluded that all constructs that meet the criteria are valid and reliable. This is indicated by the composite reliability value above 0.70 and AVE above 0.60 as recommended criteria.

\subsubsection{Collinearity Statistics (VIF) Testing}

Multicollinearity can also be seen from the value of tolerance and Variance Inflation Factor (VIF). A low tolerance value equals a high VIF value. The research data requirements are normally distributed and free from multicollinearity symptoms in smartPLS, requiring a VIF value below 5 .

Table 4.7 Collinearity Statistic (VIF)

\begin{tabular}{|l|c|l|l|l|}
\hline \multicolumn{1}{|c|}{$\begin{array}{c}\text { Research } \\
\text { Variables }\end{array}$} & $\begin{array}{c}\text { Job } \\
\text { Satisfaction }\end{array}$ & Compensation & Competence & $\begin{array}{c}\text { Performance } \\
\text { Assessment }\end{array}$ \\
\hline Job Satisfaction & & & & \\
\hline Compensation & 3,826 & & 1,963 & \\
\hline Competence & 4,075 & & & \\
\hline $\begin{array}{l}\text { Performance } \\
\text { Assessment }\end{array}$ & 2,215 & & 1,963 & \\
\hline
\end{tabular}

Source: Data processing with SmartPLS, 2021

Based on the results of the multicollinearity test above, all research data on each model construct is free from multicollinearity symptoms, for this reason these results have met the prerequisite test.

\subsubsection{Structural Model Testing (Inner Model)}

Testing of the inner model or structural model is carried out to see the relationship between the construct, significance value and R-square of the research model. The structural model was evaluated using R-square for the dependent construct of the t-test and the significance of the coefficients of the structural path parameters. In assessing the model with PLS, it begins by looking at the R-square for each dependent latent variable. Table 4.7 is the result of R-square estimation using SmartPLS.

Table 4. 8 Value R-Square

\begin{tabular}{|l|c|c|}
\hline & R Square & R Square Adjusted \\
\hline Job Satisfaction & 0,543 & 0,530 \\
\hline Competence & 0,755 & 0,750 \\
\hline
\end{tabular}


Source: Data processing with PLS, 2021

In principle, this study uses 2 variables that are influenced by other variables, namely the Job Satisfaction variable (Y) which is influenced by Compensation (X1) and Performance Appraisal (X2) and the Competence variable (M) as a mediating variable which is influenced by Compensation (X1) and Performance Assessment (X2). Table 4.8 shows the $\mathrm{R}$-square value of 0.543 showing the magnitude of the simultaneous influence of the Compensation variable, Competency-mediated Performance Assessment on Job Satisfaction of $54.3 \%$. The R-square value of 0.755 on the Competence variable was obtained indicating that the magnitude of the influence of the Compensation and Performance Appraisal variables on the Competence mediation was $75.5 \%$.

\subsection{Hypothesis test}

Hypothesis testing aims to test the relationship between variables in the research construct whether it is accepted or rejected. The significance of the estimated parameters provides very useful information about the relationship between the research variables. The basis used in testing the hypothesis is the value contained in the output result Path Coefficients. Table 4.9 provides output for structural model testing.

Table 4. 9 Direct effect between variables (Path Coefficients)

\begin{tabular}{|l|c|c|c|c|c|}
\hline \multicolumn{1}{|c|}{ Direct effect } & $\begin{array}{c}\text { Original } \\
\text { Sample } \\
(\mathbf{O})\end{array}$ & $\begin{array}{c}\text { Sample } \\
\text { Mean } \\
(\mathbf{M})\end{array}$ & $\begin{array}{c}\text { Standard } \\
\text { Deviation } \\
\text { (STDEV) }\end{array}$ & $\begin{array}{c}\text { T Statistic } \\
(\text { O/STDEV) }\end{array}$ & $\begin{array}{c}\text { P } \\
\text { Value }\end{array}$ \\
\hline $\begin{array}{l}\text { Compensation } \\
\text { Job Satisfaction }\end{array}$ & 0,563 & 0,570 & 0,103 & 5,447 & 0,000 \\
\hline $\begin{array}{l}\text { Compensation } \\
\text { Competence }\end{array}$ & 0,676 & 0,675 & 0,056 & 12,148 & 0,000 \\
\hline $\begin{array}{l}\text { Competence } \\
\text { Job Satisfaction }\end{array}$ & 0,538 & 0,532 & 0,194 & 2,712 & 0,006 \\
\hline $\begin{array}{l}\text { Performance } \\
\text { Assessment } \\
\text { Job Satisfaction }\end{array}$ & 0,164 & 0,162 & 0,124 & 1,315 & 0,189 \\
\hline $\begin{array}{l}\text { Performance } \\
\text { Assessment } \\
\text { Competence }\end{array}$ & 0,249 & 0,253 & 0,066 & 3,768 & 0,000 \\
\hline
\end{tabular}

Source: Data processing with PLS, 2021

In the smartPLS test, statistically each hypothesized relationship is carried out using simulation. To see whether or not there is an influence between the variables of the research construct, it can be seen from the P value below 5\% $(<0.005)$. In addition, to assess the relationship between variables having a positive or negative relationship can be seen from the Original Sample, if it shows a positive value the relationship between related variables has a positive value, and vice versa. In this case, the bootstrap method is applied to the sample. Testing with bootstrap is also intended to minimize the problem of abnormal research data.

In the construct of the research model, the Compensation and Performance Appraisal variables are mediated by Competence, the relationship between these variables can be read through Table 4.10 
Table 4.10 Spesific Indirect Effects

\begin{tabular}{|l|c|c|c|c|c|}
\hline Indirect effect & $\begin{array}{c}\text { Original } \\
\text { Sample } \\
(\mathbf{O})\end{array}$ & $\begin{array}{c}\text { Sample } \\
\text { Mean (M) }\end{array}$ & $\begin{array}{c}\text { Standard } \\
\text { Deviation } \\
\text { (STDEV) }\end{array}$ & $\begin{array}{c}\text { T Statistic } \\
\text { (O/STDEV) }\end{array}$ & $\begin{array}{c}\text { P } \\
\text { Value }\end{array}$ \\
\hline $\begin{array}{l}\text { Compensation } \rightarrow \\
\text { Competence } \\
\text { Job Satisfaction }\end{array}$ & 0,364 & 0,361 & 0,140 & 2,601 & 0,010 \\
\hline $\begin{array}{l}\text { Performance } \\
\text { Assessment } \\
\begin{array}{l}\text { Competence } \\
\text { Job Satisfaction }\end{array}\end{array}$ & 0,134 & 0,135 & 0,061 & 2,187 & 0,029 \\
\hline
\end{tabular}

Source: Data processing with PLS, 2021

Based on the results of the bootstrapping test above, the relationship between variables in the model construct can be analyzed as follows:

The direct effect between Compensation to Job Satisfaction.

Based on the results of testing the first hypothesis, it shows that the provision of compensation has an effect on job satisfaction. This result is shown from the $\mathrm{P}$ value of 0.000 and the original sample of 0.563 . Thus the first hypothesis (H1) is accepted. The results of this study are in line with previous research Sofyandi (2013:162); This also supports research from T. Retnoningsih, B.S Sunuharjo, I. Ruhana, (2016) which states that there is a strong relationship between compensation and employee job satisfaction.

\section{The direct effect between Compensation to Competence}

Based on the results of testing the second hypothesis, it shows that the provision of compensation has an effect on competence. This result is shown from the $\mathrm{P}$ value of 0.000 and the original sample of 0.676 . Thus the second hypothesis $(\mathrm{H} 2)$ is accepted. The results of this study are in line with previous research, namely Septerina and Rusda Irawati (2018) in addition, Yunus (2012); Klarner, et al., (2013); Rudlia (2016). which explains that the provision of Compensation must be based on the competency criteria of employees.

\section{The direct effect between Performance Assessment to Job Satisfaction}

Based on the results of testing the third hypothesis, it shows that Performance Appraisal has no effect on Job Satisfaction. This result is shown from the P value of 0.189 (> 0.005) and the original sample of 0.164 . Thus the third hypothesis (H3) is rejected. The results of this study are not in line with previous research, namely January, Utami, Ruhana (2015) which argues that performance appraisal has an effect on job satisfaction, even further explained that the better the implementation of performance appraisal, the higher job satisfaction. Andari, Nafiudin (2019) explained that performance appraisal has a positive effect on employee job satisfaction.

\section{The direct effect between Performance Assessment to Competence}

Based on the results of testing the fourth hypothesis, it shows that Performance Assessment has an effect on Competence. This result is shown from the $\mathrm{P}$ value of 0.000 and the original sample of 0.249 . Thus the fourth hypothesis (H4) is accepted. The results of this study are in line with previous research, namely Wibowo (2014); Supatmi, Nimran, \& Utami, (2013) who explained that there is a strong relationship between Performance Appraisal and Employee Competence.

\section{The direct effect between Competence to Job Satisfaction}

Based on the results of testing the fourth hypothesis, it shows that competence has an effect on job satisfaction. This result is shown from the $\mathrm{P}$ value of 0.000 and the original sample of 0.538 . Thus the fifth hypothesis (H5) is accepted. The results of this study are in line with previous research, namely Mathis and Jackson (2002:81) and Dessler, (2004:70) which explain that there is a strong correlation between Performance Appraisal and Employee Competence. 


\section{Indirect Effect of Competence through Competence on Job Satisfaction}

Based on the results of testing the sixth hypothesis, it shows that, Compensation through Competence has an effect on Job Satisfaction. This result is shown from the P value of 0.010 and the original sample of 0.364 . Thus the sixth hypothesis (H6) is accepted. The results of this study are in line with previous studies, namely Yunus (2012); Klarner, et al., (2013); Nazir et al. (2013); Rood and Holdnak (2013); Rizwan (2014); Adeoye and Fields (2014); Salisu et al. (2015); Muguongo et al. (2015); Rudlia (2016); Rahayu and Riana (2017); Septerina and Rusda Irawati (2018) explain that there is a significant effect of giving compensation based on competence to fulfill employee job satisfaction.

\section{Indirect Effect of Performance Assessment through Competence on Job Satisfaction}

Based on the results of testing the seventh hypothesis, it shows that, Compensation through Competence has an effect on Job Satisfaction. This result is shown from the P value of 0.029 and the original sample of 0.134 . Thus the seventh hypothesis (H7) is accepted. The results of this study are in line with previous research, namely Supatmi, Nimran, \& Utami, (2013) and Wibowo (2014), which explain that there is a significant effect of a Performance Assessment based on Competence will meet employee job satisfaction.

\section{CONCLUSIONS AND SUGGESTIONS \\ Conclusion}

Based on the analysis and discussion in the previous section, the following conclusions can be drawn:

1. A direct compensation will have a significant effect on employee job satisfaction. Compensation can be a work motivation as the actualization of satisfaction with the management award for the individual/employee. The compensation provided can be in the form of facilities or non-financial compensation for the achievement of its performance.

2. A compensation given based on consideration of individual competence is a form of management appreciation for employee professionalism, so this attitude also triggers motivation for other employees to further improve their individual professionalism.

3. Employee performance appraisal directly does not affect employee job satisfaction, this is due to the existence of an element of superior subjectivity to certain individual assessments so that it cannot fulfill a sense of justice in the eyes of employees. Based on the results of this study, it can be used as input to make improvements to the governance of human resource management.

4. Employee performance appraisal based on individual competence is considered more fulfilling the sense of justice and management professionalism in managing human resource management.

5. Employee competence is proven to have an influence in fulfilling job satisfaction. Competence is the most basic thing in building employee professionalism.

6. Compensation given to employees based on consideration of individual competence will provide job satisfaction. This can be measured by increasing the achievement of employee performance. Non-financial compensation such as providing housing facilities and work vehicles can increase work discipline and employee loyalty to the company. Likewise, financial compensation in the form of performance bonuses is able to motivate the achievement of targeted performance for these employees.

7. Performance appraisals based on individual competencies are considered to be able to fulfill a sense of satisfaction at work, because the achievement of work performance is really calculated objectively by management.

\section{Limitations}

The implementation of the research still has several limitations, namely:

1. Research variables related to employee job satisfaction can still be developed such as by adding leadership styles, work environment and others, so it is hoped that this research 
can be developed in further research, to complement and enrich scientific discoveries in management science that can be directly implemented directly. real in industry.

2. This research has only been conducted in the manufacturing industry and may not have been carried out in the digital industry which measures the performance of its employees based on public responses such as the e-commerce industry and public official agencies.

\section{Suggestions}

Based on the limitations in this study, it is expected that:

Further research can develop points from the limitations described above, both the development of research variables and indicators and respondent sampling.

\section{REFERENCES}

Aamir, Alemzeb. 2012 "Compensation Methods and Employees Motivation" (With Reference to Employees of National Commercial Bank Riyadh) College of Business Administration, King Saud University, Riyadh, Saudi Arabia. Jurnal Internasional dari Sumber Daya Manusia ISSN 2162-3058 Studi pada tahun 2012, Vol. 2, (3)

Adeoye, Abayomi., and Fields, Ziska. 2014. Compensation Management and Employee Job Satisfaction: A Case of Nigeria. Journal of Social and Science. 41(3): 345-352.

Andari, Nafiudin, 2019. Pengaruh Motivasi Dan Penilaian Prestasi Terhadap Kepuasan Kerja Karyawan Pada PT Surya Indah Persada Indonesia Di Kota Serang. Jurnal Ekonomi Vokasi, Vol. 2 No 2 Juli 2019 ISSN 2622-4240

C. I. Januari, H. N. Utami, I. Ruhana 2015. Pengaruh Penilaian Kinerja Terhadap Kepuasan Kerja Dan Prestasi Kerja. Jurnal Administrasi Bisnis (JAB), Vol. 24 No. 2 Juli 2015 administrasibisnis.studentjournal.ub.ac.id

D. Kenelak. R.J. Pio, S.G. Kaparang, 2016. Pengaruh Kompensasi Terhadap Kinerja Karyawan Pada Koperasi Serba Usaha Baliem Arabica Di Kabupaten Jayawijaya, Jurnal Administrasi Bisnis 2016.

Desler, Gerry. 2010 Manajemen Sumber Daya Manusia. Jakarta: PT Indeks.

Handaru, Agung W., dan Nailul, Muna. 2012. Pengaruh Kepuasan gaji dan komitmen organisasi terhadap turnover intention pada karyawan PT. Unitex di Bogor. Jurnal Riset Manajemen Sains Indonesia. 3(1).

Hasibuan, Malayu SP. 2005. Manajemen Sumber Daya Manusia, Edisi revisi, Jakarta : Bumi Aksara

Hasibuan, Malayu S.P, 2011, Manajemen Sumber Daya Manusia, Edisi Revisi, Cetakan Kelima belas, PT. BumiAksara, Jakarta.

Hasibuan, Malayu SP. 2012. Manajemen Sumber Daya Manusia, Edisi revisi ketujuh, Jakarta : PT. Bumi Aksara.

H. Maheswari, 2017. Pengaruh Kompensasi Dan Motivasi Terhadap Kinerja Karyawan PT. Bank Ekonomi Raharja, Tbk Area Jakarta 5. Jurnal Manajemen,

DOI:10.24912/jm.v19i2.126, https://www.researchgate.net/publication/322005473

Iqbal, Saba., Ehsan, Sadia., Lecturer, M., Rizwan, and Noreen, M. 2014. The Impact of organizational commitment, job satisfaction, job stress and leadership support on 
turnover intention in educational institutes. International Journal of Human Resource Studies. 4(2).

Klarner, P., Sarstedt, M., Hoeck, M., and Ringle, C.M. 2013 "Disentangling the Effects of Team Competences, Team Adaptability, and Client Communication on the Performance of Management Consulting Teams”. Long Range Planning. 46 (3): 258- 286.

Mangkunegaran, Prabu. 2012. Evaluasi Kinerja Sumber Daya Manusia Bandung: Refika Aditama.

M. Kadarisman. 2012. Manajemen Kompensasi, Jakarta: Rajawali Pers.

Moeheriono. 2010. Pengukuran Kinerja Berbasis Kompentensi. PT. Bumi Aksara, Jakarta.

Muguongo, Mary Makena., Muguna, Andrew t., and Muriithi, Dennis. 2015. Effects of Compensation on Job Satisfaction Among Secondary School Teachers in Maara Sub County of Tharaka Nithi County, Kenya. Journal of Human Resources Management. 3(6): 47-59.

Nazir, Tahira., Hussain, Syed Fida., and Zaman, Khalid. 2013. Impact of Rewards and Compensation on Job Satisfaction: Public and Private Universities of UK. Journal of ScientificResearch. 14(3): 394-403.

N. Firmandani, 2014. Pengaruh Kompensasi Terhadap Kinerja Karyawan Dengan Motivasi Kerja Sebagai Variabel Moderasi. Jurnal Ekonomi Dan Bisnis Islam, EKBISI, Vol. IX, No. 1, Desember 2014, hal. 25 - 34. ISSN:1907-9109

N.M.N. Rahayu, I. Riana 2017. Pengaruh Kompensasi Terhadap Kepuasan Kerja Dan Keinginan Keluar Pada Hotel Amaris Legian. E-Jurnal Manajemen Unud, Vol. 6, No. 11, 2017: 5804-5833 ISSN : 2302-8912

Permatasari, Sufian, Rachmansyah, 2019. Analisis Pengaruh Motivasi Kerja, Kompetensi Dan Beban Kerja Terhadap Kinerja Pegawai Dengan Disiplin Kinerja Sebagai Variabel Moderasi. Jurnal Magisma Vol. 7 No. 1 - Tahun 2019.

Purwanto, Asbari, Santoso, 2019. Pengaruh Kompetensi, Motivasi, Kepemimpinan, Komitmen Dan Budaya Kerja Sistem Manajemen Integerasi ISO 9001, ISO 14000, Dan ISO 45000 Pada Industri Otomotif. Jurnal Produktifitas 6, 2019.

Rivai, Veithzal dan Mohd Basri. 2012. Performance Appraisal. Jakarta: Raja Grafindo Persada

Rivai, Veithzal. 2012. Manajemen Sumber Daya Manusia untuk Perusahaan.

Rood, A. Scott., and Holdnak, Andrew. 2013. An Analysis of Compensation Patterns and Job Satisfaction Issues of Resort Recreation Professionals. Journal of Tourism Insights. $4(1)$.

Ronald E.Walpole. Pengantar Statistika, halaman 2-5". 1993. Jakarta: PT Gramedia Pustaka Utama. ISBN 979-403-313-8

Rudlia, J.I. 2016 "Pengaruh Kompetensi dan Kompensasi terhadap Kepuasan Kerja dan Kinerja Pegawai (Studi Kasus Pada Dinas Kelautan dan Perikanan Kabupaten Kepulauan Sangihe)". Jurnal Riset Bisnis dan Manajemen. Vol 4, No.3: 257-268. 
Salisu, Jamilu B., Chinyio, Ezekiel., and Suresh, Subashimi. 2015. The impact of compensation on the job satisfaction of public sector construction workers of jigawa state of Nigeria. The Business and Management Review. 6(4).

Sinollah, 2020. Analisis Penilaian Kinerja Terhadap Kepuasan Dan Dampaknya Terhadap Kinerja. Jurnal Ekonomi Dan Ilmu Sosial. Vol5, No.1, Febuari 2020.

Sofyandi, Herman. 2013. Manajemen Sumber Daya Manusia. Edisi Pertama. Cetakan Ke-2. Yogyakarta: Graha Ilmu.

Supatmi, M. E., Nimran, U., \& Utami, H. N. 2013. Pengaruh Pelatihan, Kompensasi terhadap Kepuasan Kerja Karyawan dan Kinerja Karyawan. Jurnal Profit. https://doi.org/10.9876/10.9876/VOL1ISSN1978-743X

Surikha, 2016. Pengaruh Kompensasi Dan Pengembangan Karir Terhadap Kinerja Pegawai Dengan Quality Of Work Life (QWL) Sebagai Faktor Pemoderasi, Jurnal Citra Widya Edukasi Vol VIII No. 2 Agustus 2016

Sutanto, Eddy M., dan Carin, G. 2013. Kepuasan kerja, komitmen organisasional dan turnover intentions. Jurnal Mitra Ekonomi dan Manajemen Bisnis. 4(7): 76-88.

T. Retnoningsih, B.S Sunuharjo, I. Ruhana, 2016. Pengaruh Kompensasi Terhadap Kepuasan Dan Kinerja Karyawan. Jurnal Administrasi Bisnis (JAB), Vol. 35 No. 2 Juni 2016.

Wibowo, 2012. Manajemen Kinerja. Edisi Ketiga. Jakarta. PT Raja Grafindo Persada.

Wibowo. 2014. Manjemen Kinerja. Edisi Ke-empat. Jakarta: Rajawali Pers

Yucel, Ilhami. 2012. Examining the relationship among job satisfaction, organizational commitment and turnover intention: an impirical study. International Journal of Bussiness and Management. 7 20): 44-55.

Yunus, E. 2012 "Pengaruh Kompetensi Sumber Daya Manusia Terhadap Kinerja Pegawai Kppbc Tipe Madya Pabean Tanjung Perak Surabaya". Ekuitas: Jurnal Ekonomi dan Keuangan. No. 110/DIKTI/Kep/2009 ISSN 1411-0393.

Wibowo, 2013. Manajemen Kinerja. PT Raja Grafindo Persada, Jakarta.

Wibowo. 2012. Manajemen Kinerja Edisi Ketiga. Jakarta : PT. RajaGrafindo Persada.

Suhartini, Eka., 2012. Kualitas pelayanan kaitannya dengan kepuasan konsumen. Alauddin University Press.

Suhartini, Eka., 2013. Motivasi, Kepuasan Kerja dan Kinerja. Samata: Alauddin University Press 78 